\title{
Filling of the Vertical Mine Workings with the Au- toclave Slag-concrete
}

\author{
Uglyanitca Andrey V. ${ }^{\mathrm{a}}$, Solonin Kirill D. ${ }^{\mathrm{b}}$ \\ T.F. Gorbachev Kuzbass State Technical University+ \\ Kemerovo, Russian Federation \\ auav@kuzstu.ru; bsolonin_kirill@mail.ru
}

\begin{abstract}
The results of laboratory experimental research in the production of the filling autoclaved slag-concrete made of slag wastes and lime are considered in the article, the methods of filling of abandoned vertical mine workings with the slagconcrete blocks, which are made either directly in the mine working or on the surface of the mine. The developed ways of a backfill will allow to ensure ecological safety of the territories adjacent to the vertical mine working and at the same time to utilize technogenic slag waste of the fuel and energy enterprises, also as a result of this research nonshrinking and waterproof autoclave concrete and technology of its production will find an application in a construction complex as alternative cement concrete, and can be used in construction of the bases, walls, dams, dikes, and other precast concretestructures.
\end{abstract}

Keywords - vertical mine workings, filling, slag-lime mixture, mixture parameters, autoclave curing, steam curing hole, slag-concrete.

\section{INTRODUCTION}

The restructuring of the coal industry in Russia is being carried out since 1994. 188 coal mines were abandoned in Russia during this period, including 42 Kuzbass mines. The process of abandonment of unprofitable mines and the out-oflife vertical mine workings goes on.

According to requirements, the vertical shafts and pits driven in unstable rocks and having unsatisfactory roof supports must be completely filled with the low-shrinkage waterproof material up to the ground level. The resulting filling mass is to prevent the hydraulic connection between aquifers, the exit of mine gas to the surface and cavings on the territories adjacent to the vertical mine workings.

To date, about 500 vertical shafts are abandoned in the closed mines in Russia, including 157 - in Kuzbass mines. According to the requirements, some vertical workings under abandonment were blocked in the collar by two platforms between which the burned rock was filled; others were completely filled with the rock up to the ground level, the rock reserves being made near the workings; while others were completely filled with the rock up to the ground level and covered with two sturdy platforms made of reinforced concrete or metal beams in accordance with the applicable instructions.

According to the Audit Chamber of the Russian Federation, the abandonment and flooding of the majority of mines led to the large changes in the hydrogeological conditions of the bowels, the earth surface, and the atmosphere in the settlements. As a result of the closure of mines, the natural state of the terrain, surface and ground water, atmospheric boundary layer are disturbed on an area of about 90 thousand hectares. The water pollution with the high-mineralized man-made water of the abandoned mines containing the elements such as manganese is 300 times higher than the maximum permissible limits.

First of all, this is due to the complexity and magnitude of unresolved environmental problems, as well as the fact that development of mine abandonment projects had the serious flaws $[1,2]$.

One of the reasons that have caused the extensive environmental degradation in the areas adjacent to the abandoned mines is the lack of clear requirements for the filling materials for the vertical mine workings in the current instructions.

On the one hand, it is indicated that the filling material must ensure the stability of mine workings and prevent the disturbance of the hydrogeological conditions of groundwater, that is to be dimensionally stable and waterproof, and at the same time, it is recommended to fill the abandoned workings with the rocks.

For stability it is necessary to use the materials that do not shrink during the protected period and to apply the waterproof materials to prevent disturbance of the hydrogeological conditions of groundwater.

No rock possesses these properties together. The largesized hard rocks are dimensionally stable, but the size of the cavities and therefore the filtration coefficient of that filling mass will be great. In addition, this filling material will not interfere with the exit of mine gas to the surface. The fine rocks (eg, clay), have the low coefficient of filtration, but the compression of such rocks is significant, and as a consequence, they will give greater shrinkage. The incoherent material filled into the shaft settles at the vertical mine working under the influence of gravitational forces. The value of this shrinkage can reach $50 \%$. Since the shaft collar is covered by concrete blocks, it is impossible to exercise the shrinkage control and re-filling of the material. The resulting voids in the mined-out space will lead to the cavings on the ground surface.

Thus, we can conclude that the filling of the vertical mine opening should be performed with the hardening mixtures, which form a non-shrinking waterproof massif. These activities, in spite of the initial costs, reduce the overall costs 
by reducing the cost of maintenance of the mine life in the period of its technical abandonment and the subsequent mining and environmental monitoring, as well as significantly improve the environmental and hydrological situation in the areas adjacent to the abandoned mines and return into circulation the considerable land areas.

In Russia, the methods of the layered filling of the vertical mine workings with the hardening mixtures are developed. These methods use the expensive cement or concrete hardening mixtures based on mining and metallurgy wastes, containing a large number of cement-lime binders and special additives for the filling mass production [3].

The effective filling material for the abandonment of the vertical openings is the autoclaved slag concrete produced on the basis of the ash wastes of fuel and energy enterprises and the lime. It is known that curing of the slag and lime concrete mixture depending on the mixture parameters it is possible to produce the autoclave slag concrete with a wide range of physical and mechanical properties [4].

Therefore, by autoclaving the slag-lime filling mixture it is possible to obtain the water-resistant and dimensionally stable filling mass based on the cheaper, containing a smaller amount of binder and special additives, filling slag-lime mixtures.

At present, the annually produced fuel-power industry slag waste in Russia is used by only $10 \%$. The amount of the accumulated ash waste only in Kuzbass makes up 92 million tons with an annual growth rate of 2.5 million tons. The heaps of ash and slag waste occupy more than 20 thousand hectares in the Russian Federation and urgently require the disposal. The use of ash and slag waste for the filling of mine workings will utilize the waste that will be positively reflected on the ecological state of the territories of the Russian Federation [5].

In this regard, it is urgent to develop the technological methods of filling the abandoned vertical mine workings with the autoclave slag-concrete.

\section{SUBJECT OF RESEARCH}

The aim is to establish patterns and justify the technological parameters in the process of forming in the vertical mine workings to be liquidated of the unshrinkable and waterproof filling mass of the autoclave slag concrete produced on the basis of ash and slag waste and lime.

The scientific novelty of the work is in:

- identification of dependence of compression and filtration properties of the autoclave slag-concrete on the slag-lime mixture parameters and autoclave processing parameters;

- identification of dependences of the distribution of water vapor from the steam injector in the filling mixture made of milled slag and lime at its autoclave processing;

- study and development of ways of filling vertical mine workings with autoclave slag-concrete.

The developed methods of backfilling will ensure the environmental safety of the territories adjacent to the abandoned vertical mine working at minimal labor and material costs and, at the same time, disposal of man-made slag waste of fuel and energy enterprises.

\section{RESULTS AND DISCUSSIONS}

The laboratory experimental studies of compression and filtration properties of the autoclaved slag-concrete carried out in KuzSTU showed that the milled slag and lime mixtures of autoclave hardening mode can be used for filling the vertical mine workings. However, it is only possible to get the waterproof and unshrinkable filling mass under certain weight ratios of components of the mixture, its chemical compositions and autoclaving regimes [6,7,8,9,10,11].

Table 1 shows the compositions of the slag-lime mixtures and their autoclaving parameters set as a result of these studies for the production of waterproof and unshrinkable slag-concrete.

TABLE I. PARAMETERS OF SLAG-LIME MIXTURES AND THEIR AUTOCLAVING PROCESS, UNDER WHICH THE SAMPLES DIDN'T SHRINK AND PROVED TO BE WATERPROOF

\begin{tabular}{|c|c|c|c|c|c|c|c|}
\hline 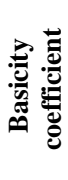 & & ๘0 & & 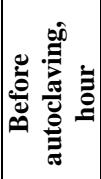 & 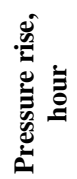 & . & 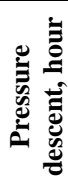 \\
\hline 0,3 & 0,08 & 0,08 & 0,5 & 4 & 0,75 & 6 & 5 \\
\hline 0,4 & 0,08 & 0,08 & 0,5 & 4 & 0,75 & 6 & 5 \\
\hline 0,5 & 0,08 & 0,16 & 0,5 & 4 & 0,75 & 6 & 5 \\
\hline 0,7 & 0,16 & 0,16 & 0,5 & 4 & 0,75 & 6 & 5 \\
\hline 0,7 & 0,16 & 0,16 & 0,5 & 6 & 0,75 & 4 & 4 \\
\hline 0,8 & 0,16 & 0,16 & 0,5 & 4 & 0,75 & 6 & 5 \\
\hline 0,9 & 0,16 & 0,16 & 0,8 & 4 & 0,75 & 6 & 5 \\
\hline
\end{tabular}

The basicity coefficient of the slag-lime mixture $K_{\text {осн }}$ depends on the chemical composition of slag and characterizes the capacity of mixture to be complexed into calcium monosilicate and is calculated according to the formula [7, $9,10,11,12]$

$$
\mathrm{K}_{\text {осн }}=\frac{\left(\mathrm{CaO}+0,93 \mathrm{MgO}+0,6 \mathrm{R}_{2} \mathrm{O}\right)-\left(0,55 \mathrm{Al}_{2} \mathrm{O}_{3}+0,35 \mathrm{Fe}_{2} \mathrm{O}_{3}+0,7 \mathrm{SO}_{3}\right)}{0,93 \mathrm{SiO}_{2}}
$$

where $\left(\mathrm{CaO}+0,93 \mathrm{MgO}+0,6 \mathrm{R}_{2} \mathrm{O}\right)$ - the total $\mathrm{CaO}$, \%; $0,55 \mathrm{Al}_{2} \mathrm{O}_{3}+0,35 \mathrm{Fe}_{2} \mathrm{O}_{3}+0,7 \mathrm{SO}_{3}$ - the amount of $\mathrm{CaO}$, bound by the oxides and not participating in silicating, $\% ; 0,93 \mathrm{SiO}_{2}$ - the amount of $\mathrm{CaO}$ to add to $\mathrm{SiO}_{2}$ to form calcium monosilicate, $\%$.

Two ways to fill the vertical mine workings with the autoclaved slag-concrete were developed in KuzSTU, the first method involves filling the vertical working with the cylindrical autoclave slag-concrete blocks, prefabricated on the surface of the mine [13], the second method provides for the fabrication of such blocks directly in the vertical mine working [13].

The filling of the vertical mine workings with the blocks prefabricated on the surface of the mine (the first method) is as follows (Fig. 1). The level openings 1 are sealed in the areas of their junction with a vertical working 2 by building 
the wall 3. The cylindrical autoclave slag-cement blocks 4 are delivered and stcked near the collar.

The specified number of blocks is put down in the shaft, then the calculated amount of concrete mix 6 is conveyed through the concrete pipeline 5 into the space between the walls of the vertical working and blocks 7 . Before putting down the blocks into the shaft the layer of waterproofing mastic 8 is applied on its upper surface. The blocks are put down into the shaft by the crane or the special headstock.

The radius of the cylindrical concrete block is taken less than the radius of the vertical working, taking into account the irregularities of its walls, so that that the cylinder block during its travel down the vertical working is not jammed.

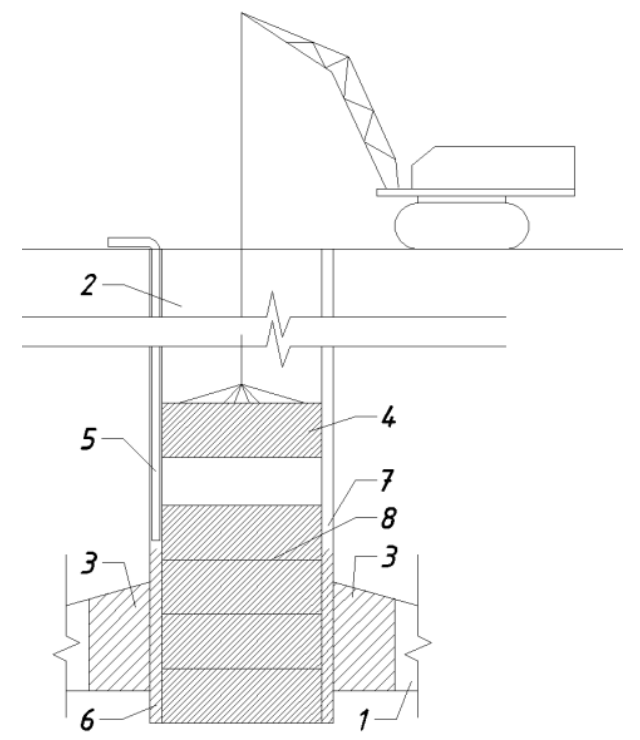

Fig. 1. The scheme of the filling of the vertical mine working with the cylindrical autoclave slag-concrete blocks prefabricated on the mine's surface

The filling of the vertical mine working with the cylindrical autoclave slag-concrete blocks manufactured directly in the abandoned working (method 2) is performed as follows (Fig. 2).

According to the developed filling method, the filling layers for the vertical mine working in the form of the cylindrical autoclave slag-concrete blocks are fabricated directly in the vertical mine working, in sequence one above the other in the upward direction.

The filling is performed as follows. The level openings 1 are sealed in the areas of their junctions with the vertical working 2 by building concrete walls 3 . In the vertical mine working all the shaft equipment (buntons, guide tubes, cables, etc.) is dismantled.

The mobile mechanized sollar-packer 5 with a ring sealer 6 is installed above the prefabricated cylindrical autoclave slag-concrete block 4 at the predetermined distance from it.
The walls of the vertical working 7, sollar-packer 5 and prefabricated cylindrical autoclave slag-concrete block 4 form the autoclave chamber for the production of the cylindrical autoclave slag-concrete block.

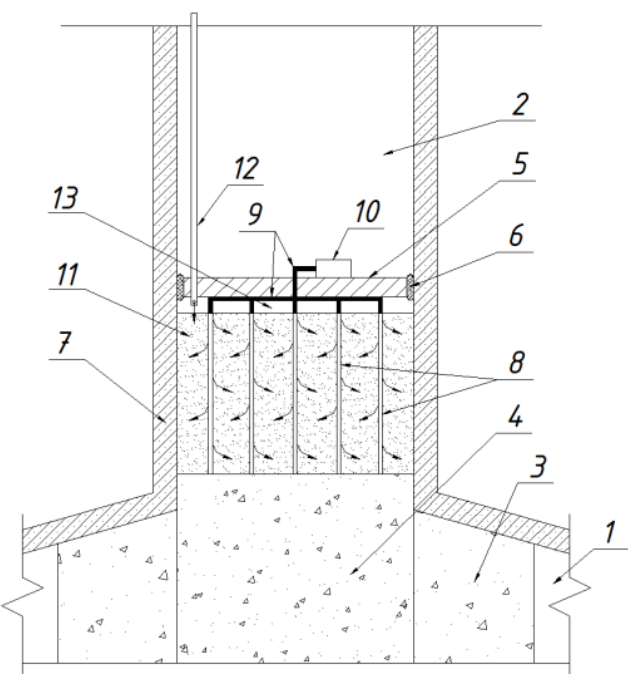

Fig. 2. The scheme of the filling of the vertical mine working with the cylindrical autoclave slag-concrete blocks, fabricated directly in the mine working

The steam curing holes 8 , which connect the steam pipe 9 to the steam generator 10 , are installed between the sollar 5 and the prefabricated cylindrical autoclave slag-concrete block 4.

The slag-lime mixture 11 is placed in the autoclave chamber, conveying it behind the sollar-packer 5 through the concrete pipeline 12. The distance from the bottom surface of the sollar-packer 5 to the prefabricated autoclave slagconcrete block 4 must be greater than the height of the fabricated autoclave slag-concrete block by $100 \mathrm{~mm}$, for the autoclave chamber with the exposed surface of 13 above the placed filling slag-lime mixture. The height of slag-concrete blocks is taken according to its construction and is equal to $2.0-3.0 \mathrm{~m}$.

The composition of filling slag-lime mixture, the parameters of its autoclaving and the distance between the steaming wells in the form of an autoclave chamber are calculated to produce the filling autoclave slag-concrete with the required compression and filtration properties according to the recommendations presented in Tables 1 and 2.

The steam is supplied to the steaming wells autoclaving the filling mixture. The autoclaved autoclave slag-concrete blocks having been fabricated; the mechanized sollar-packer is moved upwards for the manufacture of the next overlying block, etc.

The technology, according to which the concrete blocks are produced in the autoclave chamber with the use of steaming wells [14], is developed in KuzSTU for the fabrication of the huge autoclaved slag-concrete blocks. At this, the autoclaving of concrete mixture in the autoclave chamber is performed through the exposed surface of concrete in the chamber, and also through the steaming wells, 
which are arranged in the concrete mix at the predetermined distance from each other.

The fabrication of the blocks according to the developed technology is as follows. The vertical steaming wells 2 made of tubes with walls permeable to steam but impermeable to concrete, are adjusted to the height of the mixture placement in the metal mold 1 (Fig. 3) which performs the autoclave function; the steaming wells being interconnected by the mounting fittings 3 and the concrete mixture 4 being placed and vibrotampered to prove the stability.
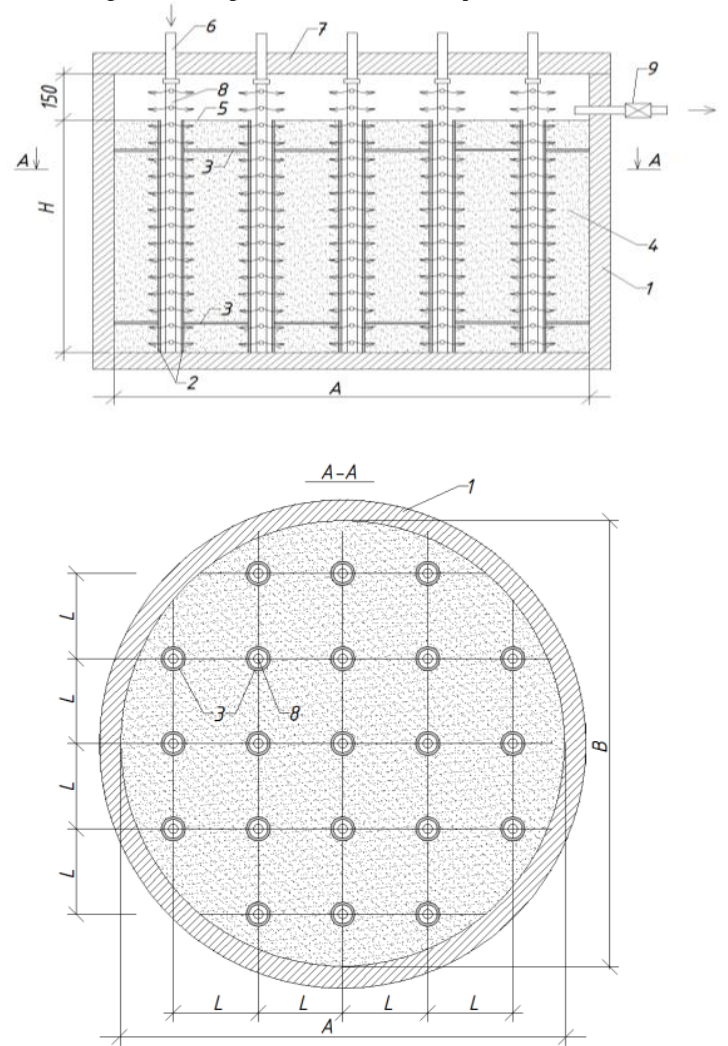

Fig. 3. Autoclave chamber for the fabrication of the huge slag-concrete blocks

When placing the concrete mix the $100 \mathrm{~mm}$ wide gap is left between the mold cover and the mixture surface to create the exposed surface 5 of the concrete mixture 4 in the mold 1 .

The perforated tubes - steam injectors -8 are attached to the steam supplying pipes 6 in the mold cover 7 against the steaming wells 2 . The cover 7 is installed on the mold 1 ; the steam injectors being placed inside the steaming wells 2 and bottoming the mold 1 .

The steam under the pressure is fed into the steam injectors 8 and the concrete mixture 4 is autoclaved via its exposed surface 5 and steaming wells 2 . While autoclaving the condensate is removed via the purge valve 9 .

After autoclaving of concrete mixture 4 and concrete cooling, the cover 7 is removed from the mold 1 and the molded concrete block is removed. The steaming wells 2 in the block are concreted.

The distance between the steaming wells $L$ in the mold is calculated depending on the radius of the autoclaving spread from the steaming well into the filling mix.
The experimental laboratory test-bed model "Radial autoclave" was designed to study the autoclaving spread in the slag-lime mixtures from the steaming well.

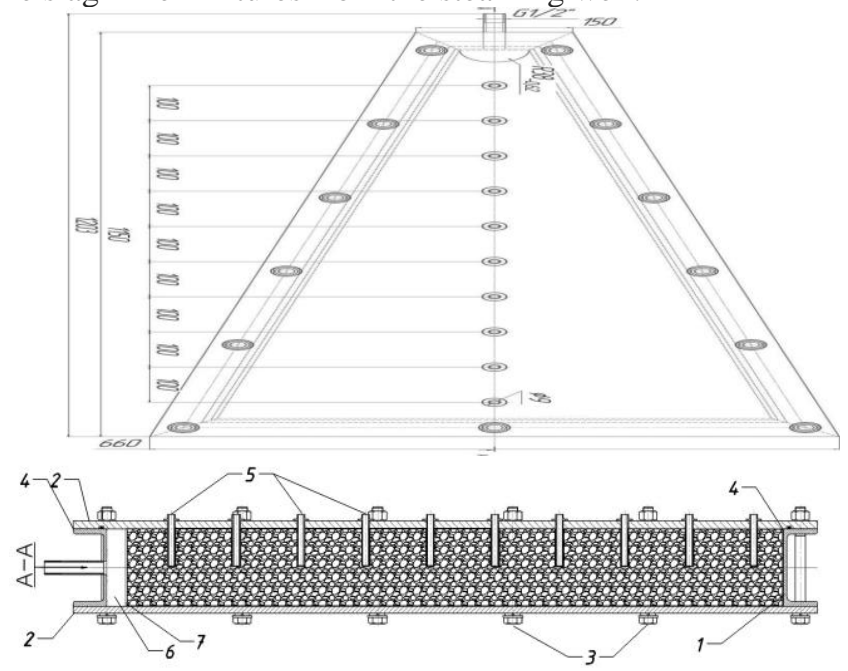

Fig. 4. Laboratory test-bed model "Radial autoclave"

The experimental laboratory test-bed is a prefabricated metal structure designed as a sector with a $30^{\circ}$ vertex angle (Fig. 4) consisting of the frame 1 and two covers 2. The upper cover is removable to provide the placement of the filling into the autoclave chamber. To ensure the tightness of the "Radial autoclave" the upper cover is connected to the frame by the bolt connections 3. The paronite packing is placed on the high-temperature sealant 4 between the frame and the cover. Ten wells 5 are mounted in the upper cover for placing the thermometers. The distance between the wells is $100 \mathrm{~mm}$.

The steaming well of the test-bed is designed as the 76 $\mathrm{mm}$ diameter sector. The wall of the well is made of metal mesh 7 permeable to the steam but impermeable to the slaglime mixture. The laboratory steam generator PGE-15MD with the boiler volume of 15 liters was used to supply the water vapor in the steaming well. The mixture was placed in the radial autoclave, then it was covered with the lid. The water vapor was fed under pressure into steaming well sector and the filling mixture was autoclaved.

After the pre-autoclaving curing of the placed mixture the water vapor was fed into the radial autoclave chamber. The pressure in the autoclave chamber was built up to the maximum of $1.2 \mathrm{MPa}$. This was due to the fact that the autoclaved slag-concrete strength does not increase under the vapor pressure above $1.2 \mathrm{MPa}$ [4].

Autoclaving of the mixture and the determination of the effective radius of its spreading from the steaming well were performed as follows.

To prepare the filling mixture, the milled slag and the lime were mixed until homogeneous and tempered with water. The resulting mixture was filled in an autoclave chamber of the experimental test-bed and the experiment was made. The temperature of the mixture of the sample was measured by the liquid thermometers. The indications of the thermometers were recorded before the start of the pressure descent cycle in the autoclave chamber. The compositions of 
filling mixture and the autoclaving parameters presented in Table 1 were used in the experiments.

The number of the identical experiments was determined on the basis of preliminary experiments equal to 5 [15].

The effective autoclaving radius was determined by the temperature of the mixture in the autoclave as follows. There is the correlation between the vapor pressure and the temperature of the filling mixture in the closed system under autoclaving. The minimum $0.9 \mathrm{MPa}$ value of the water vapor pressure when the autoclave synthesis of the filling mixture occurs [4] corresponds to the temperature of $174.53^{\circ} \mathrm{C}$. When the isothermal surface of the steamed mixture is spread from the steaming well, the pressure and therefore the temperature are gradually decreased. In this case, the limit of the effective radius of the autoclaving spread from the steaming well is considered to be the radius at which the mixture temperature was $175^{\circ} \mathrm{C}$.

Based on the results of the conducted research, the radii of the spread of the efficient autoclaving of the filling mixture from the steam injector depending on the parameters of filling mixture and its autoclaving were determined. The results are summarized in Table. 2.

\section{TABLE II. AUTOCLAVING RADII DEPENDING ON THE MIXTURE COMPOSITION AND AUTOCLAVING PARAMETERS}

\begin{tabular}{|c|c|c|c|c|c|}
\hline $\begin{array}{c}\text { Radiu } \\
\mathbf{s , ~} \mathbf{m}\end{array}$ & $\begin{array}{c}\text { Basicity } \\
\text { coefficien } \\
\mathbf{t}\end{array}$ & $\begin{array}{l}\text { Lime } \\
\text { (fract } \\
\text { ion) }\end{array}$ & $\begin{array}{c}\text { Slag } \\
\text { (fract } \\
\text { ion) }\end{array}$ & $\begin{array}{l}\text { Water } \\
\text { ratio }\end{array}$ & $\begin{array}{c}\text { Autoclaving } \\
\text { regimes, } \\
\text { hour }\end{array}$ \\
\hline 0,6 & 0,3 & 0,08 & 0,08 & 0,5 & $4+0,75+6+5$ \\
\hline 0,4 & 0,4 & 0,08 & 0,08 & 0,5 & $4+0,75+6+5$ \\
\hline 0,4 & 0,5 & 0,08 & 0,16 & 0,5 & $4+0,75+6+5$ \\
\hline 0,6 & 0,7 & 0,16 & 0,16 & 0,5 & $4+0,75+6+5$ \\
\hline 0,4 & 0,7 & 0,16 & 0,16 & 0,5 & $6+0,75+4+4$ \\
\hline 0,4 & 0,8 & 0,16 & 0,16 & 0,5 & $4+0,75+6+5$ \\
\hline 0,2 & 0,9 & 0,16 & 0,16 & 0,8 & $4+0,75+6+5$ \\
\hline
\end{tabular}

\section{CONCLUSIONS}

The developed options of the technology of backfilling vertical mine workings with autoclave-slag concrete including the innovative method of large-size concrete blocks production in autoclave form will ensure favourable environment in the areas adjacent to the liquidated vertical mine working (preventing caving on the surface and establishing of hydraulic connection between aquifers, firedamp emission, etc.) by creating an impermeable nonshrink backfill in the vertical mine working, as well as disposal of ash and slag waste from thermal power stations of Siberia and other RF regions.

\section{REFERENCES}

[1] Ludzish V. S. Gidrogeologicheskie problemy likvidacii shaht Kuzbassa i puti ih resheniya / EKO-bjulleten' InEkA № 6 (137), 2009.Novokuzneck : OOO «InEkA-konsalting»,S. $44 \square 47$.

[2] Likvidacii opasnogo proizvodstvennogo objekta OOO «Shahta Tyrganskaya» Obshaya poyasnitel'naya zapiska : proektnaya dokumentaciya : PD79-2009.P-G / Tom 1 / gl. inzh. A. A. Bychkovskiy. - Kemerovo : OOO «Sibgeoproekt», 2010. - 238 s.
[3] Korneeva E. V. Kompozicionnoe bescementnoe vyazhushhee iz promyshlennyh othodov i zakladochnaya smes' na ego osnove / E. V. Korneeva, S. I. Pavlenko. $\square$ M. : Izdatel'stvo Asso-ciacii stroitel'nyh vuzov, 2009., 139 s.

[4] Bozhenov P. I. Tehnologiya avtoklavnyh materialov. $\square$ L. : Strojizdat, Leningr. otd-nie, 1978. $\square 368 \mathrm{~s}$.

[5] Doklad vice-prezidenta «Nacional'noy associacii proizvoditeley potrebiteley ZShM» O.A. Novoselova na kruglom stole «Obrashhenie s othodami proizvodstva i potrebleniya: problemy i resheniya», Sovet Federacii Federal'nogo Sobraniya, 15.11.13.

[6] Isaenko A. V., Ugljanica A. V. Issledovanie zavisimosti kompressionnyh svojstv avtoklavnyh zakladochnyh materialov na osnove toplivnyh shlakov ot parametrov zakladochnoy smesi [Vestnik KuzGTU]. 2011. № 1. S. 34 - 37.

[7] Isaenko A. V. , Ugljanica A. V. Issledovanie zavisimosti kompressionnyh svojstv avtoklavnyh zakladochnyh materialov na osnove toplivnyh shlakov ot parametrov ih avtoklavnoy obrabotki [Vestnik KuzGTU]. 2011. № 2. S. 15 - 19.

[8] Ugljanica A. V., Hmelenko T.V., Solonin K.D. Issledovanie zavisimosti fil'tracionnyh svojstv zakladochnyh avtoklavnyh materialov na osnove toplivnyh shlakov ot parametrov zakladochnoj smesi. [Vestnik KuzGTU]. 2012. № 3. S. $59-62$.

[9] Ugljanica A. V., Hmelenko T.V., Solonin K.D. Issledovanie zavisimosti fil'tracionnyh svojstv zakladochnyh avtoklavnyh materialov na osnove toplivnyh shlakov ot parametrov parametrov avtoklavnoj obrabotki [Vestnik KuzGTU]. 2012. № 3. S. 63 - 67.

[10] Uglyanica A.V., Solonin K.D., Strukova E.A. Charcterization of autoclaved slag concrete for stowing the vertical mine workings under liquidation: «Research Journal of Applied Sciences», 2015, 10 (2) pp.84-91

[11]Uglyanica A.V., Khmelenko T.I., Solonin K.D.. Slag-alkaline concrete efficient building material: International journal of applied engineering research (IJAER), India, - Volume 9, Number 22 (2014) - pp. 1683716842

[12] Sposob zakladki vertikal'noy vyrabotki. Patent № 2449129. Opubl. 27.04. 2012. Bjul. №12. Avtory: IsaenkoA.V., Ugljanica A.V., Hmelenko T.V, Gladkih L.N.

[13] Sposob zakladki vertikal'noj vyrabotki. Patent № 2427712. Opubl. 27.08. 2011. Bjul. №24. Avtory: Ugljanica A.V., IsaenkoA.V., Hmelenko T.V.

[14] Sposob proizvodstva krupnogabaritnyh betonnyh blokov v formeavtoklave. Patent № 2562307. Opubl. 10.09.2015. Bjul. №25. Avtory: Ugljanica A.V., Solonin K.D., Strukova E.A

[15] Ashmarin, I. P. Bystrye metody statisticheskoj obrabotki i planirovanie jekspe-rimentov / I. P. Ashmarin, I. N. Vasil'ev, V. A. Ambrosov. L. : LGU, 1975. - $76 \mathrm{~s}$. 
[1] Ludzish V.S. Hydrogeological problems of the abandonment of Kuzbass mines and the ways of their solution / ECO-bulletin InEcA № 6 (137), November 2009 / Yanuary 2010. - Novokuznetsk: OOO « InEcAconsulting» - pp. 44-47

[2] Abandonment of hazardous industrial object OOO «Mine Tyrganskaya» General Explanatory Report: Project documentation: ПД79-2009/П$\Gamma$ / Volume 1 / chief engineer A.A. Bychkovskiy. - Kemerovo: OOO «Singeoproject», 2010. $-238 \mathrm{p}$.

[3] Korneeva E.V. Composite cement-free binder made of the indus trial waste and the filling mixture / E.V. Korneeva, S.I. Pavlenko. - Moscow: Association of construction universities, 2009. - 139 p.

[4] Bozhenov P.I. Technology of autoclave materials. - Leningrad: Strojizdat, 1978. $-368 \mathrm{p}$.

[5] The report of the vice-president of "National association of producers and consumers of ash and slag materials» O.A. Novoselov at the summit «Treatment of the industry and consumption wastes: problems and solutions», the Federation Council of the Federal Assembly, 15.11.13.

[6] The research in the dependence of the compression properties of filling autoclave materials on the basis of the fuel slag on the filling mixture parameters / Isaenko A.V., Uglyanitsa A.V. // Bulletin of KuzSTU. 2011. № 1. pp. $34-37$.

[7] The research in the dependence of the compression properties of filling autoclave materials on the basis of the fuel slag on the autoclaving parameters / Isaenko A.V., Uglyanitsa A.V. // Bulletin of KuzSTU. 2011. № 2. pp. $15-19$.

[8] The research in the dependence of the filtration properties of filling autoclave materials on the basis of the fuel slag on the filling mixture parameters

Uglyanitsa A.V., Khmelenko T.V., Solonin K.D. // Bulletin of KuzSTU. 2012. pp. $59-62$.

[9] The research in the dependence of the filtration properties of filling autoclave materials on the basis of the fuel slag on the autoclaving parameters $/$ Uglyanitsa A.V., Khmelenko T.V., Solonin K.D. // Bulletin of KuzSTU. 2012. № 3. pp. $63-67$.

[10] Uglyanica A.V., Solonin K.D., Strukova E.A. Charcterization of autoclaved slag concrete for stowing the vertical mine workings under liquidation: «Research Journal of Applied Sciences», 2015, 10 (2) - pp.84-91

[11] Uglyanica A.V., Khmelenko T.I., Solonin K.D.. Slag-alkaline concrete - efficient building material: International journal of applied engineering research (IJAER), India, - Volume 9, Number 22 (2014) - pp. 16837-16842

[12] The method for filling the vertical mine working. Patent № 2449129. Published 27.04.2012. Bul. №12. Authors: Isaenko A.V., Uglyanitsa A.V., Khmelenko T.V., Gladkikh L.N.

[13] The method for filling the vertical mine working. Патент № 2427712. Published 27.08.2011. Bul. №24. Authors: Isaenko A.V., Uglyanitsa A.V., Khmelenko T.V.

[14] The method for the production of bulky concrete blocks in the autoclave chamber. Patent № 2562307. Published 10.09.2015. Bul. №25. Authors: Uglyanitsa A.V., Solonin K.D., Strukova E.A.

[15] Ashmarin I.P. Rapid methods of statistical handling and design of experiments / I.P. Ashmarin, I.N. Vasiliev, V.A. Ambrosov. - Leningrad: LSU, 1975. - 76 p. 